\title{
Impact of power-plant discharges on marine zooplankton: A review of thermal, mechanical and biocidal effects
}

\author{
J. M. Capuzzo \\ Woods Hole Oceanographic Institution; Woods Hole, Massachusetts 02543, USA
}

\begin{abstract}
The relative importance of thermal, mechanical and biocidal stresses to marine zooplankton entrained in cooling waters from coastal power-plant operations is dependent on specific features of power-plant design and siting. Toxic effects of power-plant operations will vary with (1) the degree of mechanical stress induced by pumping velocities of cooling water; (2) the physical and chemical interaction of receiving and discharge waters; (3) the dosage of chlorine or other biocide added to cooling waters for fouling control ${ }_{i}(4)$ the exposure time to stress conditions experienced during passage through condenser conduits and discharge canals; and (5) the nature of receiving waters, affecting the production and availability of the various halogen toxicants formed upon chlorination of seawater. Because of these variables, the problem of entrainment-induced mortality of zooplankton and the resulting effects on secondary production in receiving waters is difficult to assess. A review of laboratory and field studies addressing these problems is presented and particular emphasis given to the synergistic effect of multiple stresses.
\end{abstract}

\section{INTRODUCTION}

The increased demand for coastal power stations has been complemented by an increased concern over the environmental impact of plankton entrainment in associated cooling waters. Entrained plankters may be subjected to thermal, mechanical and biocidal stresses during their passage through condenser conduits. In several recent field studies, decreased productivity of entrained phytoplankton (Morgan \& Stross, 1969; Hamilton et al., 1970; Carpenter et al., 1972) and reduced survival of entrained zooplankton (Carpenter et al., 1974a; Davies \& Jensen, 1975; Heinle, 1976) have been observed and have resulted in concern that power-plant entrainment and discharges might alter primary and secondary production in coastal receiving waters.

Entrainment-induced mortality of marine zooplankton may be a result of thermal shock due to excessive increases in $\triangle T$ beyond the thermal tolerances of entrained species, rapid pressure changes and abrasion associated with mechanical stress, or the biocidal action of chlorine or other biocides. Current chlorination practices for fouling control at coastal power stations vary from continuous low-level application $\left(0.1 \mathrm{mg} \mathrm{l}^{-1}\right.$ total residual chlorine), commonly practiced in Great Britain (Beauchamp, 1969), to intermittent additions (2-3 h per day), commonly practiced in the United States (Becker \& Thatcher, 1973). In the latter instance concentrations of chlorine in discharged cooling waters are in the range of $0.05-1.00 \mathrm{mg}^{-1}$ total residual chlorine (Brungs, 1973) and 
concentrations within this range have been shown to be toxic to serveral species of marine zooplankton (Roberts et al., 1975; Capuzzo et al., 1976; Capuzzo, 1979a). Evaluating the toxicity of chlorine to marine zooplankton is complicated by the production of several halogen toxicants upon chlorination of seawater. Wong \& Davidson (1977) confirmed that chlorine is readily replaced by free bromine compounds in seawater with low ammonia concentrations. In the presence of high ammonia and/or organic concentrations, significant production of combined halogen compounds as haloamines (Johannesson, 1958) and organohalogen compounds (Jolley, 1975) may occur.

The relative importance of thermal, mechanical and biocidal stresses to marine zooplankton entrained in cooling waters from coastal power-plant operations will vary with specific features of power-plant design, siting and operating procedures. The objective of this review is to summarize and evaluate the existing data from field and laboratory studies on the impact of coastal power plants on populations of marine zooplankton.

\section{FIELD STUDIES}

Carpenter et al. (1974a) reported copepod mortality of $\approx 70 \%$ as a result of entrainment in the cooling water system of the Millstone Nuclear Power Station, located on Long Island Sound (USA). They concluded that the observed mortality was due predominantly to mechanical damage; the impact of thermal and chlorine stresses could not be identified in the absence of mechanical stress. Zooplankters were not immediately killed by power-plant passage but died after several days in the effluent ponds adjacent to the power plant. The authors estimated that this loss of copepods resulted in a reduction of $0.1-0.3 \%$ of the zooplankton production of Long Island Sound. In further studies (Carpenter et al., 1974b), no decrease in zooplankton populations could be detected in the receiving waters adjacent to the power plant; however, the authors concluded that conventional sampling techniques were inadequate in assessing small changes in zooplankton abundance.

Heinle (1976) compared zooplankton entrainment at three fossil-fueled power plants in Maryland (USA) and concluded that thermal and mechanical stresses had little effect on entrained zooplankton but extensive zooplankton mortality was observed during periods of chlorination. In earlier studies by Heinle (1969) at the Chalk Point power plant survival of entrained zooplankton was poor when discharge temperatures exceeded $30^{\circ} \mathrm{C}$, presumably due to the combined effects of thermal and chlorine stresses; however, standing crop and production of Acartia tonsa (the dominant zooplankter) were somewhat greater during the summer following power-plant operations in comparison with pre-operational studies.

Gentile et al. (1976) in field studies at a power plant located on Narragansett Bay observed complete mortality of the copepod Acartia tonsa during periods of chlorination (1-3 $\mathrm{mg} \mathrm{l}^{-1}$ ) but no mortality in the absence of chlorination; other species of copepods (e.g., Acartia clausi) were susceptible to thermal stress as well.

In a similar study Davies \& Jensen (1975) suggested that entrainment-induced mortality of zooplankton was due to the response of individual species to ambient temperatures and $\Delta T$ rise characteristics at specific power plants, in addition to mechanical and chlorine stresses. When ambient temperatures were high and discharge temperatures did not exceed the thermal tolerance of entrained species, little zooplankton 
mortality was observed; however, prolonged exposure of both cold and warm acclimated zooplankton to a high $\Delta \mathrm{T}$ resulted in reduced survival. The responses of entrained zooplankton to chlorination were varied at different power plants, but might have been related to synergistic effects of temperature, exposure time, salinity and water quality of receiving waters. Although reduced survival of entrained zooplankton had been observed by Davies and Jensen, little reduction in zooplankton populations could be detected beyond the mixing zone of the discharged effluent. Youngbluth (1976), however, concluded that power-plant operations in a subtropical area resulted in a reduction in diversity of the zooplankton community, where Acartia tonsa was the dominant zooplankton in a thermal cove receiving discharged effluents.

To assess the sublethal effects of thermal discharges on zooplankton populations, Gaudy (1977) compared the respiratory metabolism of the copepod Acartia clausi collected at the intake and discharge $\left(\triangle \mathrm{T}=6^{\circ} \mathrm{C}\right)$ of the Martigues-Ponteau power plant in the Gulf of Fos, Mediterranean Sea, and adjacent receiving waters affected by the heated effluents. Seasonal variations in respiration rates and $Q_{10}$ were observed, but organisms collected from the heated effluents had reduced metabolic rates; copepods exposed to a simulated thermal stress showed similar reductions in metabolic rates. Gaudy suggested that the reductions in respiration rates of Acartia clausi might offer some physiological advantage in compensating the effects of thermal shock but further identification of these metabolic responses was needed.

As part of a three-year research program at the Woods Hole Oceanographic Institution to assess the combined effects of temperature and chlorine on marine plankton, collections of the copepod Acartia tonsa were made at the intake and discharge of the Cape Cod Canal Generating Station on Cape Cod Bay, Massachusetts (USA), and the Montaup Generating Station, Narragansett Bay, Massachusetts (USA); respiration rates were determined for organisms from the intake samples and compared with organisms from the discharge samples taken during periods with and without chlorination. Samples of zooplankton were collected using a 316- $\mu \mathrm{m}$ plankton net and the temperature and residual chlorine level of each sample were recorded. Immediately after collection, three replicates of twenty individuals of $A$. tonsa were isolated from each sample and placed in 5-ml microrespirometer flasks (Grunbaum et al., 1955) with $4 \mathrm{ml}$ filtered seawater. Respiration rates of copepods were measured at $22{ }^{\circ} \mathrm{C}$ at 15 -min intervals for $90 \mathrm{~min}$. The results of these experiments are presented in Table 1.

Copepods collected in the discharge at the Montaup Plant for the periods May through October 1976 and 1977 survived plant passage but showed a significant reduction $(\mathrm{P}<0.05)$ in respiration rate compared with organisms collected at the intake; no significant difference, however, was observed between organisms collected before and during chlorination. Copepods collected during July and August 1976 and 1977 at the Cape Cod Canal Plant did not survive plant passage, probably because of the high $\triangle T$ of discharge waters. The results of respiration rate measurements of copepods collected during September and October 1976 and 1977 were similar to results obtained at Montaup.

Samples collected from both power plants were brought back to the laboratory to determine what effect chlorination and plant passage had on the reproductive potential of $A$. tonsa. Three replicates of five pairs of copepods were isolated from each sample and placed in 1-1 containers filled with filtered $(1 \mu \mathrm{m})$ seawater and maintained at $20^{\circ} \mathrm{C}_{i}$ 
Table 1. Acartia tonsa. Respiration rates of individuals collected at the intake and discharge of the Montaup Generating Station (Narragansett Bay, USA) and the Cape Cod Canal Generating Station (Cape Cod Bay, USA). Mean temperatures recorded during June through September at Montaup and September through early October at Cape Cod Canal. Total chlorine residual $\left(\mathrm{Cl}_{2} \mathrm{mgl}^{-1}\right)$ measured by amperometric titration (Fischer and Porter Model No. 17T1010). Respiration rates measured at $22^{\circ} \mathrm{C}( \pm 1$ standard error; $\mathrm{N}=15)$

\begin{tabular}{|llccc|}
\hline Power plant & Sample & $\mathrm{T}^{\circ} \mathrm{C}$ & $\mathrm{Cl}_{2} \mathrm{mg} \mathrm{l}^{-1}$ & $\begin{array}{c}\text { Respiration rate } \\
\left(\mu \mathrm{l} \mathrm{O}_{2}[\mathrm{~h} \cdot 100 \text { animals }]^{-1}\right)\end{array}$ \\
\hline Montaup & Intake & 22.4 & - & $9.2(0.02)$ \\
& Discharge & 28.8 & - & $3.4(0.02)$ \\
& Discharge $+\mathrm{Cl}_{2}$ & 28.8 & 0.08 & $3.2(0.2)$ \\
Cape Cod Canal & Intake & 17.2 & - & $8.4(0.2)$ \\
& Discharge & 29.8 & - & $3.6(0.2)$ \\
& Discharge $+\mathrm{Cl}_{2}$ & 29.8 & 0.10 & $3.4(0.2)$ \\
\hline
\end{tabular}

copepods were fed daily rations of the diatom Phaeodactylum tricornutum $\left(1 \times 10^{4}\right.$ cells $\mathrm{ml}^{-1}$ ) and egg production was evaluated after 1 week. Egg-production rates of female copepods from intake and discharge samples are presented in Table 2. A significant decrease $(P<0.05)$ in egg production was measured among copepods collected in the chlorinated discharge samples from both power plants. No significant difference, however, was observed among copepods collected in the intake and non-chlorinated discharge samples from both power plants.

A summary of the various field studies is presented in Table 3. As evidenced by the wide range of responses of entrained zooplankton observed in the various studies, the degree of entrainment-induced stress will vary with specific environmental variables including temperature, water quality and duration of stress. In order to obtain reliable data for use in predicting the impact of entrainment on zooplankton populations, several laboratory studies simulating power-plant conditions have been conducted.

Table 2. Acartia tonsa. Egg production rates of individuals collected at the intake and discharge of the Montaup Generating Station (Narragansett Bay, USA) and the Cape Cod Canal Generating Station (Cape Cod Bay, USA). Mean egg production rates measured at $20^{\circ} \mathrm{C}$ and a food density of $1 \times 10^{4}$ cells ml-1 $( \pm 1$ standard error; $\mathrm{N}=15)$

\begin{tabular}{|llc|}
\hline Power plant & Sample & $\begin{array}{c}\text { Egg production rate } \\
\text { (eggs [female } \cdot \mathrm{d}^{-1} \text { ) }\end{array}$ \\
\hline Montaup & Intake & $3.2(0.2)$ \\
& Discharge & $3.4(0.1)$ \\
Cape Cod Canal & Discharge $+\mathrm{Cl}_{2}$ & $1.9(0.1)$ \\
& Intake & $3.8(0.2)$ \\
& Discharge & $3.4(0.2)$ \\
& Discharge $+\mathrm{Cl}_{2}$ & $2.0(0.1)$ \\
\hline
\end{tabular}




\section{LABORATORY STUDIES}

The singular and combined effects of thermal and chlorination stress on marine zooplankton have been evaluated in several laboratory studies. Heinle (1969) found the upper limit of thermal tolerance for Acartia tonsa to be between $30^{\circ}$ and $35^{\circ} \mathrm{C}$ when acclimation temperatures were between $20^{\circ}$ and $25^{\circ} \mathrm{C}$ and between $25^{\circ}$ and $30^{\circ} \mathrm{C}$ when acclimation temperatures were between $5^{\circ}$ and $10^{\circ} \mathrm{C}$. Reeve \& Cosper (1972), however, found that a subtropical population of $A$. tonsa, acclimated to $30^{\circ} \mathrm{C}$, could survive at

Table 3. Summary of zooplankton entrainment studies at coastal power plants

\begin{tabular}{|c|c|c|c|c|}
\hline Location & $\begin{array}{l}\text { plant } \\
\text { Generating } \\
\text { capacity } \\
(\mathrm{Mw})\end{array}$ & $\begin{array}{l}\text { Water } \\
\text { demand } \\
\left(\mathrm{m}^{3} \mathrm{~h}^{-1}\right)\end{array}$ & Principal stress & Reference \\
\hline $\begin{array}{l}\text { Millstone Point } \\
\text { Long Island Sound } \\
\text { (USA) }\end{array}$ & 650 & 95,000 & mechanical & $\begin{array}{l}\text { Carpenter et al. } \\
(1974 a, b)\end{array}$ \\
\hline $\begin{array}{l}\text { Chalk Point } \\
\text { Patuxent River, MD } \\
\text { (USA) }\end{array}$ & 730 & 114,000 & $\begin{array}{l}\text { chlorine, slight } \\
\text { thermal }\end{array}$ & Heinle (1976) \\
\hline $\begin{array}{l}\text { Vienna } \\
\text { Nanticoke River, MD } \\
\text { (USA) }\end{array}$ & 240 & 12,600 & no significant stress & Heinle (1976) \\
\hline $\begin{array}{l}\text { Morgantown } \\
\text { Potomac River, MD } \\
\text { (USA) }\end{array}$ & 1140 & 222,000 & $\begin{array}{l}\text { chlorine, slight } \\
\text { thermal }\end{array}$ & Heinle (1976) \\
\hline $\begin{array}{l}\text { Brayton Point } \\
\text { Narragansett Bay } \\
\text { (USA) }\end{array}$ & 650 & 154,000 & chlorine, thermal & $\begin{array}{l}\text { Gentile et al. } \\
(1976)\end{array}$ \\
\hline $\begin{array}{l}\text { Marshall Station } \\
\text { Lake Norman, NC } \\
\text { (USA) }\end{array}$ & 2136 & 230,400 & thermal & $\begin{array}{l}\text { Davies \& Jensen } \\
\text { (1975) }\end{array}$ \\
\hline $\begin{array}{l}\text { Chesterfield } \\
\text { James River, VA } \\
\text { (USA) }\end{array}$ & 1416 & 158,400 & $\begin{array}{l}\text { thermal, } \\
\text { chlorine }\left(>0.50 \mathrm{mgl}^{-1}\right)\end{array}$ & $\begin{array}{l}\text { Davies \& Jensen } \\
\text { (1975) }\end{array}$ \\
\hline $\begin{array}{l}\text { Indian River } \\
\text { Indian River, DL } \\
\text { (USA) }\end{array}$ & 347 & 61,200 & $\begin{array}{l}\text { mechanical (?) } \\
\text { chlorine }\left(>1.00 \mathrm{mgl}^{-1}\right)\end{array}$ & $\begin{array}{l}\text { Davies \& Jensen } \\
\text { (1975) }\end{array}$ \\
\hline $\begin{array}{l}\text { Guayanilla Bay } \\
\text { (Puerto Rico) }\end{array}$ & 1073 & $\begin{array}{l}138,000- \\
234,000\end{array}$ & - & $\begin{array}{l}\text { Youngbluth } \\
\text { (1976) }\end{array}$ \\
\hline $\begin{array}{l}\text { Martigues-Ponteau } \\
\text { Mediterranean Sea } \\
\text { (France) }\end{array}$ & - & - & thermal & $\begin{array}{l}\text { Gaudy } \\
(1977)\end{array}$ \\
\hline $\begin{array}{l}\text { Montaup } \\
\text { Narragansett Bay } \\
\text { (USA) }\end{array}$ & 500 & 12,250 & thermal, chlorine & this study \\
\hline $\begin{array}{l}\text { Cape Cod Canal } \\
\text { Cape Cod Bay } \\
\text { (USA) }\end{array}$ & 1100 & 78,000 & thermal, chlorine & this study \\
\hline
\end{tabular}


$35^{\circ} \mathrm{C}$. Gonzales (1974) compared the critical thermal maxima and upper lethal temperatures of $A$. tonsa and $A$. clausi. $A$. tonsa was found to have a wider thermal range than $A$. clausi and therefore has a relatively better capacity to withstand thermal stress. Gonzales suggested that the thermal adaptation of $A$. tonsa is manifested in the shifting of lethal limits, reproduction and metabolic activities in response to the acclimation temperature, allowing this species to tolerate a wide range of thermal stresses. One could conclude from these findings that acclimation temperature is an important factor in thermal tolerance and that thermal stress from power-plant operations is less severe for eurythermal species than stenothermal ones.

To compare the effects of free and combined halogen toxicants and temperature on Acartia tonsa, continuous flow bioassay units were designed to allow short-term toxicant and/or thermal stress, rapid elimination of these stress conditions, and subsequent longterm observation of the test organisms (Capuzzo et al., 1976). The toxicity of free chlorine and chloramine to copepods acclimated at $10^{\circ} \mathrm{C}$ with $\triangle 0^{\circ}, \triangle 5^{\circ}$ and $\triangle 10^{\circ} \mathrm{C}$ increases in exposure temperature and copepods acclimated at $20^{\circ} \mathrm{C}$ with $\triangle 0^{\circ}, \triangle 5^{\circ}, \triangle 8^{\circ}$ and $\triangle 10^{\circ} \mathrm{C}$ increases in exposure temperature were compared. Copepods were exposed to the temperature-toxicant stress for $30 \mathrm{~min}$ and mortality was assessed $48 \mathrm{~h}$ later using the neutral red staining technique described by Capuzzo (1979b). After the 30-min exposure, residual halogen levels were chemically eliminated by the addition of sodium thiosulfate and the temperature was reduced to the acclimation temperature. Control experiments included exposure of copepods to the temperature stresses with no toxicant additions and exposure to seawater previously dechlorinated with sodium thiosulfate. The copepods were not fed during the exposure period but were maintained on the diatom Phaeodactylum tricornutum $\left(1 \times 10^{4}\right.$ cells $\left.\mathrm{ml}^{-1}\right)$ during the remainder of the 48-h experimental period.

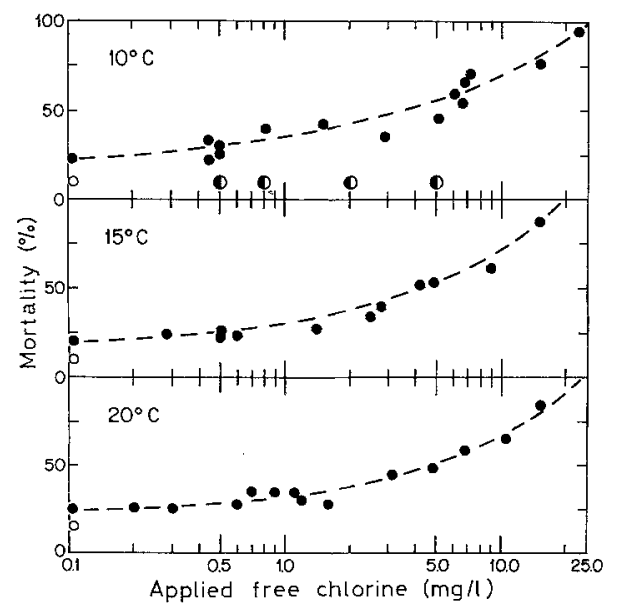

Fig. 1. Acartia tonsa. Percent mortality $48 \mathrm{~h}$ after 30-min exposure to applied free chlorine at $10^{\circ} \mathrm{C}, 15^{\circ} \mathrm{C}$ and $20^{\circ} \mathrm{C}$; copepods acclimated at $10^{\circ} \mathrm{C}$ i open circles - control mortality; open half-circles - dechlorinated before addition of test organisms

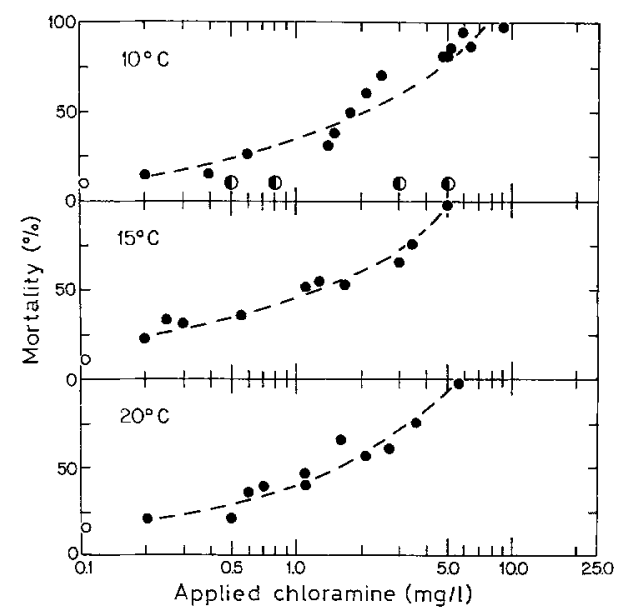

Fig. 2. Acartia tonsa. Percent mortality $48 \mathrm{~h}$ after 30-min exposure to applied chloramine at $10^{\circ} \mathrm{C}, 15^{\circ} \mathrm{C}$ and $20^{\circ} \mathrm{C}$; copepods acclimated at $10^{\circ} \mathrm{C}_{i}$ open circles - control mortality; open half-circles - dechlorinated before addition of test organisms 


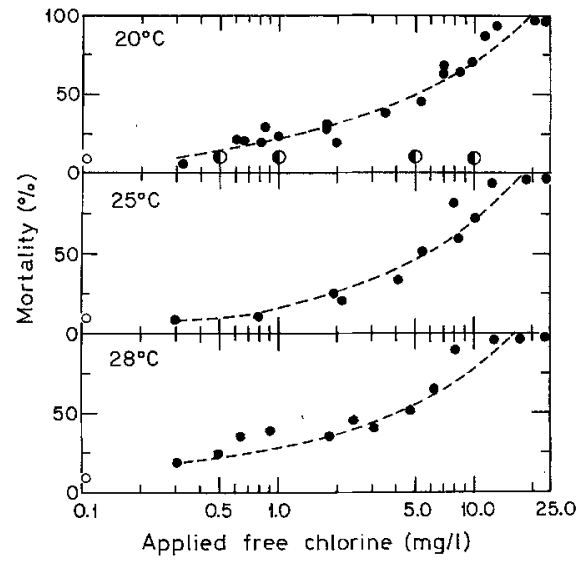

Fig. 3. Acartia tonsa. Percent mortality $48 \mathrm{~h}$ after 30-min exposure to applied free chlorine at $20^{\circ} \mathrm{C}, 25^{\circ} \mathrm{C}$ and $28^{\circ} \mathrm{C}$; copepods acclimated at $20^{\circ} \mathrm{C}$; open circles - control mortality; open half-circles - dechlorinated before addition of test organisms

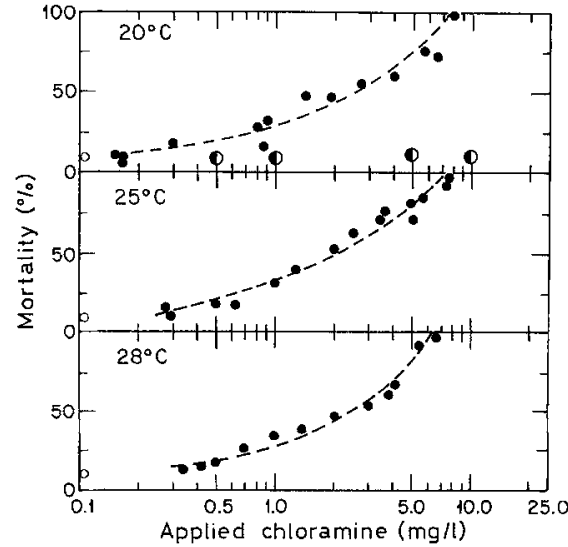

Fig. 4. Acartia tonsa. Percent mortality $48 \mathrm{~h}$ after 30 -min exposure to applied chloramine at $20^{\circ} \mathrm{C}, 25^{\circ} \mathrm{C}$ and $28^{\circ} \mathrm{C}$ i copepods acclimated at $20^{\circ} \mathrm{C}_{i}$ open circles - control mortality; open half-circles - dechlorinated before addition of test organisms

Toxicant concentrations are reported as both applied and residual levels. In all tests chloramine was more toxic than free chlorine to copepods. For copepods acclimated at $10^{\circ} \mathrm{C}$, there was no effect of temperature on the toxicity of either halogen form (Figs 1 and 2). For copepods acclimated at $20^{\circ} \mathrm{C}$, no effect of temperature was observed at $25^{\circ} \mathrm{C}$ or $28{ }^{\circ} \mathrm{C}$ (Figs 3 and 4); however, at $30^{\circ} \mathrm{C}$ thermal stress alone resulted in $60 \%$ mortality of test organisms and higher mortality was observed with exposure to the toxicants. A comparison of $\mathrm{LC}_{50}$ values (applied and residual) at the various toxicant-temperature stresses is presented in Table 4. It is concluded, therefore, that thermal effects on chlorine toxicity are only important when this species' thermal limit is approached.

In laboratory experiments with other species of zooplankton - both holoplanktonic and meroplanktonic forms - the synergistic effect of temperature in enhancing the toxic effects of chlorinated cooling waters has been demonstrated (Capuzzo, 1979a); this effect is possibly due to an interaction of uptake rates and regulation of physiological rates and the greatest enhancement in sensitivity could be expected at the upper limit of thermal tolerance. Gentile et al. (1976) and Heinle \& Beaven (1977) have demonstrated the synergistic effect of exposure time on the toxicity of chlorinated seawater to marine copepods.

The only estimates of the toxicity of alternative biocides (bromine chloride, ozone, etc.) to marine zooplankton are the data reported by Bradley (1977) on the comparison of bromine chloride and chlorine toxicity to the copepods Eurytemora affinis and Acartia tonsa. There was no significant difference in the toxicity of either biocide and this might suggest that the addition of bromine chloride to seawater results in the production of halogen toxicants similar to those produced upon chlorination of seawater.

The egg-production rates of laboratory exposed Acartia tonsa were evaluated using techniques similar to those described for field-collected copepods. Copepods were exposed to $1.00 \mathrm{mg} \mathrm{l}^{-1}$ applied free chlorine or chloramine for $30 \mathrm{~min}$ at $25^{\circ} \mathrm{C}_{i}$ after the 
Table 4. Acartia tonsa. Comparison of $\mathrm{LC}_{50}$ values of chlorine and chloramine for individuals acclimated at $10^{\circ} \mathrm{C}$ and $20^{\circ} \mathrm{C}$

\begin{tabular}{|c|c|c|c|c|}
\hline \multicolumn{2}{|c|}{ Temperature $\left({ }^{\circ} \mathrm{C}\right)$} & \multirow{2}{*}{$\begin{array}{l}\text { Chlorine } \\
\text { toxicant }\end{array}$} & \multirow{2}{*}{$\begin{array}{c}\mathrm{LC}_{50}-\mathrm{mg} \mathrm{l}^{-1} \\
\text { applied }\end{array}$} & \multirow{2}{*}{$\begin{array}{l}\text { Chlorine* } \\
\text { residual }^{+}\end{array}$} \\
\hline Acclimation & Exposure & & & \\
\hline \multirow[t]{6}{*}{10} & 10 & free chlorine & 4.80 & 0.82 \\
\hline & 15 & & 4.80 & 0.82 \\
\hline & 20 & & 4.80 & 0.82 \\
\hline & 10 & chloramine & 2.10 & 0.34 \\
\hline & 15 & & 1.50 & 0.23 \\
\hline & 20 & & 1.50 & 0.23 \\
\hline \multirow[t]{6}{*}{20} & 20 & free chlorine & 4.80 & 0.82 \\
\hline & 25 & & 5.00 & 0.86 \\
\hline & 28 & & 4.80 & 0.82 \\
\hline & 20 & chloramine & 2.00 & 0.32 \\
\hline & 25 & & 2.00 & 0.32 \\
\hline & 28 & & 2.00 & 0.32 \\
\hline \multicolumn{5}{|c|}{$\begin{array}{l}\text { "LC } \mathrm{LC}_{50} \text { values determined by log-probit analysis (Finney, 1971) } \\
+ \text { Chlorine (or its derivatives) disappears from seawater fairly rapidly but the reasons for this } \\
\text { disappearance or "chlorine demand" have been difficult to identify (Goldman et al., 1979). The } \\
\text { "lost chlorine" must remain suspect as the basis for potentially toxic compounds to marine biota } \\
\text { In these experiments y (residual) }=0.18 \times \text { (applied) }-0.04, \mathrm{r}=0.88, \mathrm{~N}=30\end{array}$} \\
\hline
\end{tabular}

exposure period copepods were maintained on a diatom culture of Phaeodactylum $\left(1 \times 10^{4}\right.$ cells $\left.\mathrm{ml}^{-1}\right)$ at $20^{\circ} \mathrm{C}$ and egg production was evaluated for 1 week following exposure. Although the growth rates of individual copepod stages were not estimated, the duration of development from egg to adult was estimated for both control and exposed groups.

The egg-production rates of each group of copepods are presented in Table 5. Eggproduction rates were significantly reduced $(P<0.05)$ for both chlorine and chloramine exposed groups, but there was no significant difference in the effect of either toxicant or in development time $(\approx 18$ days) for any of the three groups. From the mean values of eggs per female per day (E) and the duration of development (D), the daily population reproductive rate $(B)$ was calculated $(B=E / D)$. These results are presented in Table 5 .

Table 5. Acartia tonsa. Egg production of individuals exposed to free chlorine or chloramine in laboratory experiments. Mean egg production rates measured at $20^{\circ} \mathrm{C}$ and a food density of $1 \times 10^{4}$ cells $\mathrm{ml}^{-1}$ ( \pm 1 standard error; $\mathrm{N}=12$ )

\begin{tabular}{|lcc}
\hline Toxicant & $\begin{array}{c}\text { Eggs (female } \cdot \text { day }^{-1} \\
(\mathrm{E})\end{array}$ & $\begin{array}{c}\text { Daily population reproductive rate } \\
(\mathrm{B})\end{array}$ \\
\hline Control & $4.0(0.1)$ & 0.22 \\
Free chlorine* $^{*}\left(1.00 \mathrm{mg} \mathrm{l}^{-1}\right)$ & $1.8(0.2)$ & 0.10 \\
Chloramine $^{*}$ & $1.6(0.1)$ & 0.09 \\
$\left(1.00 \mathrm{mg} \mathrm{l}^{-1}\right)$ & & \\
${ }^{*}$ Equivalent to $0.15 \mathrm{mg} \mathrm{l}^{-1}$ residual chlorine &
\end{tabular}


In a similar study (Capuzzo, 1979b) the effects of the halogen toxicants on the feeding rates and egg production rates of the rotifer Brachionus plicatilis were evaluated. Rotifers surviving exposure to either chlorine or chloramine had significantly lower feeding rates and egg-production rates than control animals. The reduced reproduction rates were not sustained by the second generation of rotifers and it would appear that short-term exposure to chlorinated seawater does not result in a permanent alteration in the reproductive potential of zooplankton populations.

In laboratory bioassays with meroplanktonic organisms, the sensitivity of larval lobsters (Homarus americanus; Capuzzo et al., 1976), larval oysters (Crassostrea virginica; Capuzzo, 1979a) and juvenile killifish (Fundulus heteroclitus; Capuzzo, 1979a) to chlorinated seawater has been demonstrated. In addition to acute toxic effects, exposure of larval lobsters to sublethal concentrations resulted in reduced respiration rates and growth rates (Capuzzo, 1977), suggesting that the halogen toxicants interfere with energy metabolism.

\section{CONCLUSIONS}

Although mechanical, thermal and biocidal stresses of condenser passage have been shown to affect the survival of zooplankton entrained at coastal power stations, alterations in secondary production of receiving waters have not been demonstrated. At power-plant sites where adequate dilution of cooling waters is provided even the effects of biocidal stress to zooplankton populations may not cause a serious reduction in secondary productivity because of the small percentage of the zooplankton affected and the high reproductive rates of unaffected zooplankton. The most serious impact of power-plant entrainment may be the reduced survival and/or growth of the meroplankton component of the zooplankton because of their seasonal and sporadic occurrence in the plankton. Location of power plants, however, at sites with poor dilution of cooling waters and continuous cropping of the same zooplankton populations could result in localized reductions in secondary productivity, possible changes in zooplankton communities and reduced larval recruitment.

Specific recommendations to minimize the impact of zooplankton entrainment are: (1) careful siting of new coastal power plants to provide adequate dilution of effluents; (2) control of thermal increases to coincide with seasonal ambient temperatures and the thermal tolerances of dominant zooplankton; and (3) low-level chlorination combined with dechlorination and/or rapid dilution of cooling waters.

More concern should be placed on the impact of entrainment-induced stresses on larval organisms, particularly where commercially important species may be affected and significant reductions in harvestable crop may occur. The physiological and behavioral limitations of entrained larval stages and the possible accumulation and transfer of organohalogen compounds in marine food chains have not been fully explored; both these problems may have more serious consequences for populations of marine organisms than the problem of entrainment-induced mortality and should be the subject of more extensive research.

Acknowledgements. The author wishes to thank Dr. J. C. Goldman for his critical review of this manuscript. This research was supported by U. S. Energy Research and Development Administration Contract No. E (11-1)-2532. Contribution No. 4445 from the Woods Hole Oceanographic Institution, Woods Hole, Massachusetts 02543 (USA). 


\section{LITERATURE CITED}

Beauchamp, R. S. A., 1969. The use of chlorine in the cooling water system of coastal power stations. - Chesapeake Sci. 10, 280.

Becker, C. D. \& Thatcher, T. O., 1973. Toxicity of power plant chemicals to aquatic life. USAEC, Washington, D. C. (1249), $214 \mathrm{pp}$.

Bradley, B. P., 1977. Comparison of residual biotoxicity of chlorine and bromine chloride to copepods. Univ. of Maryland, College Park, MD, 20 pp.

Brungs, W. A., 1973. Effects of residual chlorine on aquatic life. - J. Wat. Pollut. Control Fed. 45, $2180-2193$.

Capuzzo, J. M., 1977. The effects of free chlorine and chloramine on growth and respiration rates of larval Iobsters (Homarus americanus). - Wat. Res. 11, 1021-1024.

Capuzzo, J. M., 1979a: The effect of temperature on the toxicity of chlorinated cooling waters to marine animals - a preliminary review. - Mar. Pollut. Bull. 10, 45-47.

Capuzzo, J. M., 1979b. The effects of halogen toxicants on survival, feeding and egg production of the rotifer Brachionus plicatilis. - Estuar. coast. mar. Sci, 8, 307-316.

Capuzzo, J. M., Lawrence, S. A. \& Davidson, J. A., 1976. Combined toxicity of free chlorine, chloramine and temperature to stage I larvae of the American lobster Homarus americanus. Wat. Res. 10, 1093-1099.

Carpenter, E. J., Peck, B. B. \& Anderson, S. J., 1972. Cooling water chlorination and productivity of entrained phytoplankton. - Mar. Biol. 16, 37-40.

Carpenter, E. J., Peck, B. B. \& Anderson, S. J., 1974a. Survival of copepods passing through a nuclear power station on northeastern Long Island Sound, USA. - Mar. Biol. 24, 49-55.

Carpenter, E. J., Anderson, S. J. \& Peck, B. B., 1974b. Copepod and chlorophyll a concentrations in receiving waters of a nuclear power station and problems associated with their measurement. Estuar. coast. mar. Sci. 2, 83-88.

Davies, R. M. \& Jensen, L. D., 1975. Zooplankton entrainment at three mid-Atlantic power plants. J. Wat. Pollut. Control Fed. 47, 2130-2142.

Finney, D. J., 1971. Probit analysis. Cambridge University Press, Cambridge, 333 pp.

Gaudy, R., 1977. Etude des modifications du métabolisme respiratoire de populations d'Acartia clausi (Crustacea: Copepoda) après passage dans le circuit de refroidissement d'une centrale thermoélectrique. - Mar. Biol. 39, 179-190.

Gentile, J. H., Cardin, J., Johnson, M. \& Sosnowski, S., 1976. Power plants, chlorine and estuaries. U. S. Environmental Protection Agency, Ecological Research, Washington, D. C., Rept. No. 600/3-76-055, $28 \mathrm{pp}$.

Goldman, J. C., Quinby, H. L. \& Capuzzo, J. M., 1979. Chlorine disappearance in seawater. - Wat. Res. 13, 315-323.

Gonzalez, J. G., 1974. Critical thermal maxima and upper lethal temperatures for the calanoid copepods Acartia tonsa and A. clausi. - Mar. Biol. 27, 219-223.

Grunbaum, B. W., Siegel, B. V., Schulz, A. R. \& Kirk, P. L., 1955. Determination of oxygen uptake by tissue grown in an all glass differential microrespirometer. - Mikrochim. Acta 6, 1069-1075.

Hamilton, D. H., Flemer, D. A., Keefe, C. W. \& Mihursky, J. A., 1970. Power plants: effects of chlorination on estuarine primary production. - Science, N. Y. 169, 197-198.

Heinle, D. R., 1969. Temperature and zooplankton. - Chesapeake Sci. 10, 186-209.

Heinle, D. R., 1976. Effects of passage through power plant cooling systems on estuarine copepods. - Environ. Pollut. 11, 39-58.

Heinle, D. R. \& Beaven, M. S., 1977. Effects of chlorine on the copepod Acartia tonsa. - Chesapeake Sci. $18,140$.

Johannesson, J. K., 1958. The determination of monobromamine and monochloramine in water. Analyst, Lond., 83, 155-159.

Jolley, R. L., 1975. Chlorine containing organic constituents in chlorinated effluents. - J. Wat. Pollut. Control Fed. 47, 601-618.

Morgan, R. P. \& Stross, R. G., 1969. Destruction of phytoplankton in the cooling water supply of a steam electric station. - Chesapeake Sci. 10, 165-171.

Reeve, M. R. \& Cosper, E., 1972. Acute effects of heated effluents on the copepod Acartia tonsa from 
a subtropical bay and some problems of assessment. In: Marine pollution and sea life. Ed by $\mathrm{M}$. Rǔivo. Fishing News, Books Ltd., London, 250-252.

Roberts, M. H., Diaz, R. J., Bender, M. E. \& Huggett, R. J., 1975. Acute toxicity of chlorine to selected estuarine species. - J. Fish. Res. Bd Can. 32, 2525-2528.

Wong, G. T. F. \& Davidson, J. A., 1977. The fate of chlorine in seawater. - Wat. Res. 11, 971-978.

Youngbluth, M. J., 1976. Zooplankton populations in a polluted tropical embayment. - Estuar. coast. mar. Sci. $4,481-496$. 